\title{
A GPI, az SNBI és a HDI alternatív gazdasági mutatók elméleti áttekintése
}

\author{
Csuvár Ádám, ${ }^{1}$ Bánkuti Gyöngyi, ${ }^{2}$ Cseh Balázs, ${ }^{3}$ Simon Szabolcs ${ }^{4}$ Varga József ${ }^{5}$
}

\begin{abstract}
A Theoretical Overview of Alternative Economic Indicators GPI, SNBI and HDI. The paper describes some of the main economic indicators such as the Genuine Progress Indicator (GPI), Sustainable Net Benefit Index (SNBI) and the Human Development Index (HDI) that have been intended to replace or supplement Gross Domestic Product. Based on our analysis, we conclude that none of the indicators is still able to replace GDP because of the difficulties in data collection and the lack of sufficient objectivity in the types of information used. Meanwhile, each indicator draws attention to important trends that are not visible from GDP so they can provide useful signals for building and evaluating policies. The study was created for the Economics Seminar of Kaposvár (KAKTUSZ) which is organized annually by the Kaposvár University. It is closely related to the paper by Varga et al. (2018) titled "Theoretical overview of MEW and ISEW alternative economic indicators " (in the present issue) and can be conceived as a continuation of that.
\end{abstract}

Keywords alternative economic indexes, welfare indexes, genuine progress index, GPI, sustainable net benefit index, SNBI, human development index, HDI

\section{Bevezetés}

A 2016-os KAKTUSZ környezetgazdasági szekciójának egyik munkacsoportja a gazdasági jólét mércéjét és a fenntartható gazdasági jólét indexét ismertette , $A M E W$ és $a z$ ISEW alternatív gazdasági mutatók elméleti áttekintése" címü tanulmányban. ${ }^{6}$ Ezek a

1 Kaposvári Egy etem, Gazdaságtudományi Kar

Email: csuvar.adam@ke.hu

${ }^{2}$ Kaposvári Egy etem, Gazdaságtudományi Kar Email: bankuti.gy ongyi@ke.hu

${ }^{3}$ Kaposvári Egy etem, Gazdaságtudományi Kar Email: cseh.balazs2@ke.hu

4 Sapientia EMTE/Kaposvári Egyetem

${ }^{5}$ Kaposvári Egy etem, Gazdaságtudományi Kar Email: varga.jozsef@ke.hu

${ }^{6}$ Varga et al., 2018. 
mutatók a legkorábbi alternatívaként jelentek meg a GDP felváltására, kiegészítésére. A MEW GDP-hez mért különlegessége többek között a környezeti károk és a nem monetarizált kapcsolatok számbavételében mutatkozott meg. Továbbfejlesztett változata az ISEW, amely a lakossági fogyasztásból indul ki, és ehhez adja hozzá, vagy ebből vonja le az egyes, kevésbé kézzel fogható tényezőket. Az ISEW kis mértékben módosított változata a GPI, illetve az SNBI, így folytatva a hivatkozott dolgozatban megkezdett sort, tanulmányunkat ez utóbbi két mutató bemutatásával kezdjük. Végül a human fejlődés indexét ismertetjük.

\section{$\boldsymbol{G P I}^{7}$}

A GPI ${ }^{8}$ mutatót először 1995-ben az Egyesült Államokban a Redifining Progress kutatócsoport (C. Cobb - T. Halstead - J. Rowe) az ISEW mutató továbbfejlesztéseként dolgozta ki. Számítási metodológiája az eredeti index bevezetőjének, C. Cobbnak közremüködésével később, 2004-ben megújításra került. ${ }^{9}$ A GPI a GDP-ből indul ki, amit módosít a jövedelemelosztás alakulásával és a különböző társadalmi és ökológiai költségekkel és hasznokkal. A ISEW-hoz képest több új tételt tartalmaz, öt társadalmi és két környezeti kárral. A GPI kidolgozóinak megítélése szerint a mutatójuk szemlélete leginkább egy háztartás elszámolásához hasonlítható. A családok kiadásai is különböző mértékben járulnak hozzá jólétükhöz. Finnországra a '40-es (1. ábra), az USA-ra és Ausztráliára az '50-es (2-3. ábra), Kanadára a '70-es (4. ábra) évektől állnak rendelkezésre adatok. Többnyire a GDP-vel együtt ábrázolják, rámutatva a két mutató közötti eltérésekre. A GDP emelkedése elrejti a szociális és környezetvédelmi problémákat, amelyeket a GPI figyelembe vesz, így azt mutatja, hogy a világ nem olyan prosperáló, mint azt a GDP alapján hihetnénk.

Az ISEW és a GPI összehasonlító elemzéséhez alkalmas grafikont Finnországra találtunk (1. ábra). Láthatóan a mutatók egyre inkább kezdenek elválni mind a GDPtől, mind - a kezdeti összefonódás ellenére - egymástól is. Az ISEW nagyobb változásokat mutat, míg a GPI simább ugyan, de még inkább ellentétesen mozog a GDP-hez képest.

A GPI kiszámításának módszertanával magyar nyelven Görbe és Nemcsikné (1998) foglalkozott. Málovics (2012., old.: 276) Neumayerre hivatkozva ${ }^{10}$ állítja, hogy: “Az ISEW és a GPI mutatók nem egyeznek meg egymással egy az egyben, lévén egyes komponenseikre eltérö számitási kalkulust alkalmaznak a pénzbeli értékelés során...", de megjegyzi, hogy logikájuk azonos.

\footnotetext{
${ }^{7}$ Genuine Progress Indicator, valódi fejlödés indexe

${ }^{8}$ A GPI index más értelemben is használatos, néhány fontosabbak példa: Gender Parity Index a nemek egyenlő indexe, amely tükrözi a nők oktatáshoz való hozzáférést, Global Peace Index a globális béke index a nemzetek és régiók békéjének relatív pozíciója és a Global Poker Index, az index, amely rangsorolja a világszerte élő póker játékosokat.

${ }^{9}$ Talberth, Cobb, \& Slattery, 2007.

${ }^{10}$ Neumayer, 2000.
} 
1. ábra. GDP/fó (Bkt), GPI és ISEW mutatók összehasonlító grafikonja Finnországra

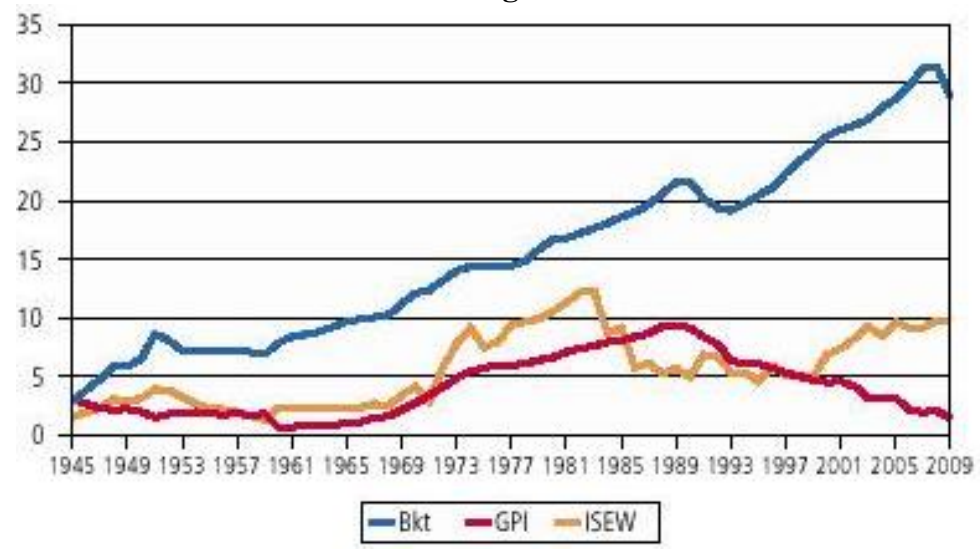

Forrás: genuineprogress.wordpress.com

[https://genuineprogress.wordpress.com/development-of-the-finnish-gpi/]

2-3. ábra. Az egy főre eső GDP és GPI alakulása az USA és Ausztrália esetében
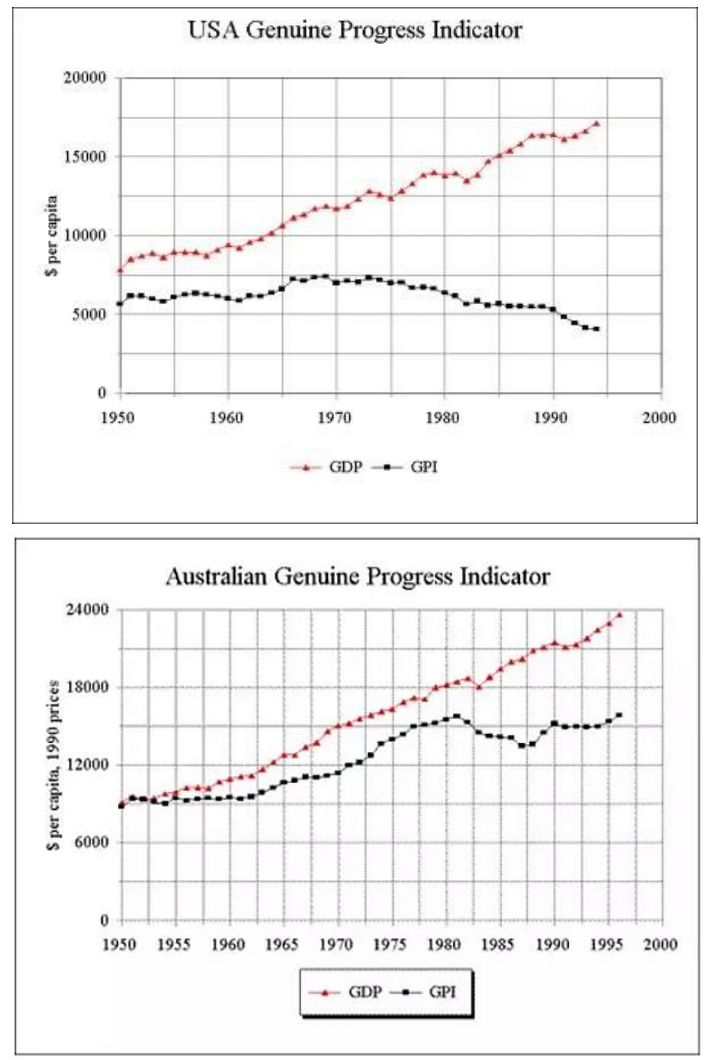

Forrás: Anielske Management

http://www.anielski.com/alberta-international-gpiisew-graphs/ 


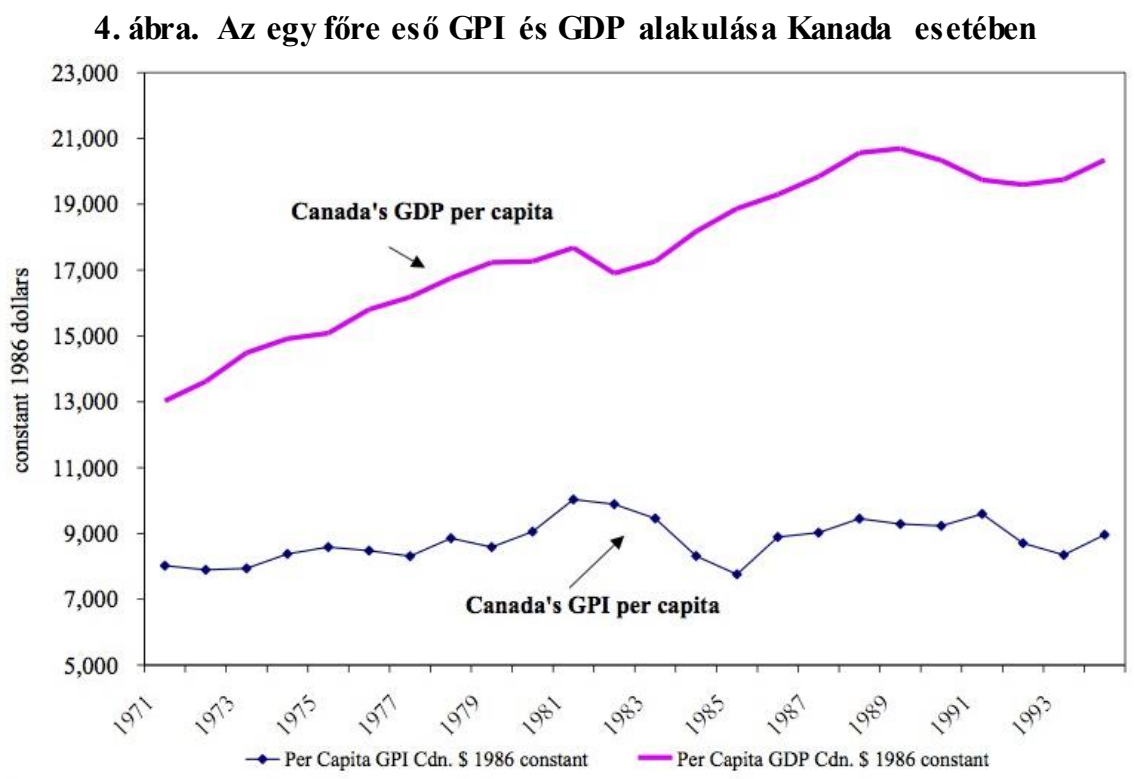

Forrás: Messinger - Tarasofsky, 1997

Az ISEW és GPI mutatók használatát a szakirodalomban számos kritika érte. ${ }^{11}$ Unyi szerint: „Több kritika érte az ISEW -et és a GPI-t, hogy az egyre növekvő szakadék a GDP és ezen mutatók éves szintje között csupán módszertani problémák eredménye. A nem megújuló energiaforrásoknak a felhasználását, és nem a kitermelését kellene alapul venni; a hosszú távú környezetkárosítást nem kellene kumulálni, mert így téves eredményre vezet; a GDP közvetlenül nem hasonlítható össze az ISEW -vel, vagy a GPI-jal, csak hosszabb időkereten belül értelmezhető. Kérdéses továbbá, hogy a meg nem újuló energiaforrások kimerülését mekkora súllyal kell számítás ba venni. Ennek mértékét önkényesen adták meg, és jelentősen hozzájárul az ISEW/GPI és a GDP közti különbség folyamatos növekedéséhez."12

\section{$S N B I^{13}$}

A fenntartható nettó haszon indexe (SNBI) a GPI-hoz hasonlóan a kevésbé materiális, sok esetben a pszichés egészséghezkapcsolódó faktorokat is számszerüsíti és hasonlítja össze. A mutató az ausztrál Lawnhoz és szerzőtársához, Sandershez köthető. ${ }^{14}$ Fontosabb különbség az előző indexekhez mérten leginkább az eredmények megjelenítésében rejlik. Az SNBI külön oldalakra helyezi a hasznokat és a károkat, így az idő elöre

\footnotetext{
${ }^{11}$ A mutatók ismertségére felmérést a Széchenyi Egyetem Kautz Gyula Közgazdász Szakkollégium ökológiai lábny om számítással foglalkozó kurzusának hallgatói végeztek (Szigeti \& Borzán, 2010). Ez megmutatta, hogy ismertségük nagy ban alulmúlja a - hangzatosabb, egy szerübb kiszámítási technológiával rendelkező, jobban elterjedt - ökológiai lábnyom indikátorét.

${ }^{12}$ Unyi, 2007., old.: 34.

${ }^{13}$ Sustainable Net Benefit Index, fenntartható nettó haszon indexe.

${ }^{14}$ Lawn \& Sanders, 1999.
} 
haladtával párhuzamosan értékelhetők a változást okozó faktorok. A mutató végső értéke a nettó pszichés hasznok oldalból kivont természeti erőforrás veszteség által jön létre.

A nettó pszichés hasznok azösszes pszichés haszon és azösszes pszichés ráfordítás különbségeként kerül meghatározásra. Ez előbbi tartalmazza

- az egyéni fogyasztási kiadásokat;

- a jövedelemelos zlás egyenlőségét; ${ }^{15}$

- a jövedelemelos zlással súlyozott egyéni fogyas ztási kiadásokat;

- a tartós fogyasztási javak, a lakások és az utak éves értékét;

- az önkéntes munka és a szabadidő értékét;

- az egés zségügyi és oktatási közkiadások értékét;

- az éves nettó tőkenövekményt,

- valamint a külföldi és hazai tőke jelenlétének arányát.

Az utóbbi, a pszichés ráfordítások kategória

- a tartós fogyasztási javak éves kiadásait;

- $\quad$ az egészségügyi és oktatási kiadásokat;

- a közlekedési balesetek költségeit;

- a zaj- és légszennyezés költségeit;

- a munkanélküliség költségeit;

- az alulfoglalkoztatás költségei (amikor valaki kevesebbet dolgozik az általa kívánatosnál);

- $\quad$ az ingázás költségeit;

- a bünözés költségeit;

- $\quad$ és a család egységének felbomlási költségeit tartalmazza.

A természeti erőforrások veszteségeként kerül számbavételbe

- az ásványiérc, a kőszén, a kőolaj, a földgáz, a nem fémes ásvány tartalékok csökkenésének költsége;

- a termőföld degradációjának, veszteségének költsége;

- a nettó erdőterület változás;

- a nettó halállomány változás;

- a lápok, mangroveerdők, sósmocsarak degradálódásának költsége;

- a víz- és légszennyezés költségei;

- a szilárd hulladék szennyezettség költsége;

- az ózonréteg csökkenésének költsége;

- a hosszútávú környezeti károk költsége;

- valamint az ökoszisztéma egészség index. ${ }^{16}$

15 A jövedelemeloszlás egyenlőtlenség a a GINI-index segítségével mérhető. A jövedelemeleloszlás gazdasági és társadalmi hatásairól ld. Varga, Kürthy, Farkas és Sipiczki (2014) tanulmányát.

${ }^{16}$ Lawn \& Sanders, 1999. 
Röviden tehát: $\mathrm{SNBI}=($ összes pszichés haszon - összes pszichés ráfordítás $)-$ természeti erőforrás veszteség

Az index megalkotói hazájuk, Ausztrália példáján vetették össze a GDP és az SNBI alakulását (5. ábra). A vizsgált időszakban, azaz a hatvanas évek közepétől hozzávetőlegesen 30 éven át, a GDP egyenletesen növekszik. Ezzel ellentétben az SNBI a hetvenes évek közepe táján elérte a csúcsát, onnantól kezdődően kisebb kilengésekkel, de egyértelmủen zuhan. A zuhanás oka, hogy a természeti erőforrások erodálódásának üteme felül múlja a lelki hasznok növekedésének ütemét, ezért a nemzetgazdaság bővülésének velejárója, hogy egy átlagos lakos jóléte folyamatosan csökken ${ }^{17}$.

5. ábra. Az egy fơre vetített GDP és SNBI változása Ausztrália esetében (1966/671994/95)

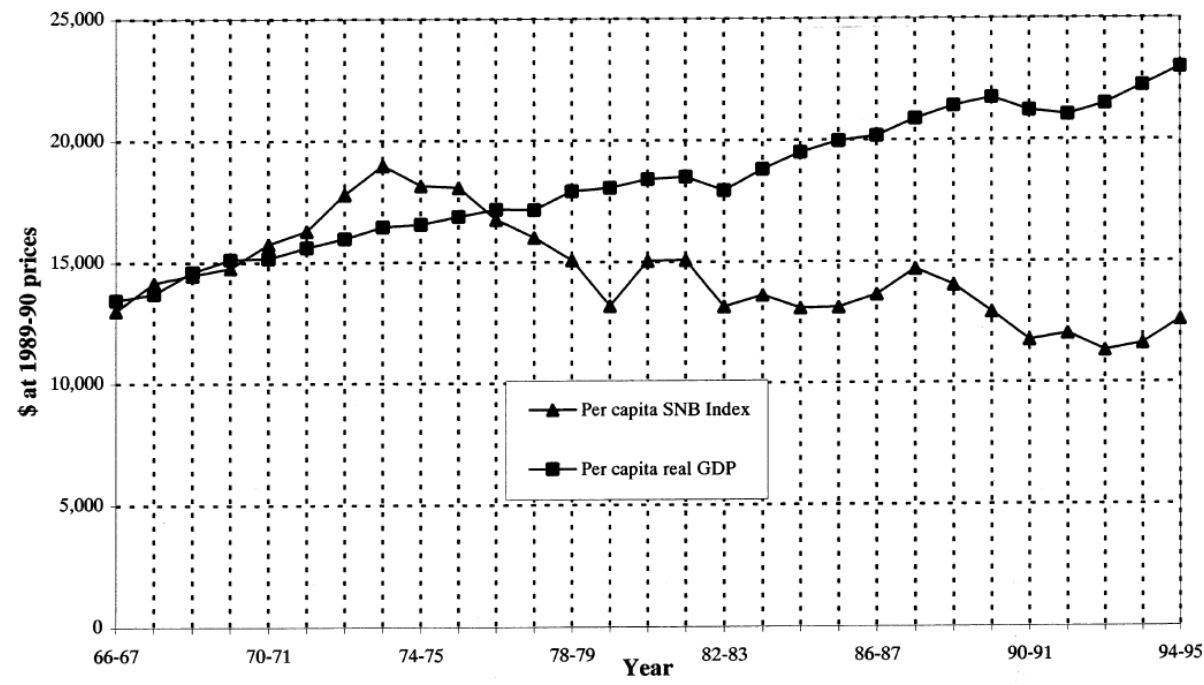

Forrás: Lawn \& Sanders, 1999

\section{$\mathrm{HDI}^{18}$}

Az egyik legrégebbi alternatív gazdasági, jóléti mutató a HDI. Az előző mutatókhoz hasonlóan a GDP-nél tágabb intervallumot vesz figyelembe, 1990 óta használatos, az ENSZ alkotta meg. Módszertanának lényege, hogy három elemet arányosít, azok meghatározott, 0 és 1 közötti értéket vehetnek fel. A módszertan érdekessége, hogy fix értékekkel dolgoznak, egy fajta skálát hozva létre ezáltal. ${ }^{19}$

Első eleme a hosszú és egészséges élet, amelyet a születéskor várható élettartam (SZVÉ) alapján határoznak meg. Ebben az esetben a két sarokszám a 25 és a 85 . A 25 a minimum értéket jelenti, a 85 a maximumot, amiből adódik, hogy ha valakinek az SZVÉ értéke 25 évnél kisebb az automatikusan 0 értéket ad a humán fejlettségi index

\footnotetext{
${ }^{17}$ Lawn \& Sanders, 1999.

${ }^{18}$ Human Development Index, humán fejlettségi index.

${ }^{19} \mathrm{KSH}, 2008$.
} 
részösszegeként, ugyanakkor a 85 év fölött pedig 1-et. 25 és 85 között pedig az alábbi az alkalmazott képlet:

$$
\frac{\text { SZVÉ }-25}{85-25}
$$

A születéskori várható élettartam meghatározása nem olyan nehéz, hiszen a legtöbb ország statis ztikai hivatala nyilvántartja ezt az adatot, ma világtávlatban ez az érték 68 év körül van. (Jelenleg Magyarországon az átlagéletkor 75,35 év (2015-ös adat), a nemeket megkülönböztetve pedig 72,09 és 78,61 év a nők javára (KSH adatbázis, 2016).)

A második tényező az iskolázottság, amelyet két részre bonthatunk. Külön súlyzókat kap a felnőtt írástudók aránya (ÍF) és a kombinált beiskolázási (KBI) arány. Az előbbiek kétharmad részét képezik ennek a mutatónak, az utóbbiak pedig a maradék egyharmadot. (Magyarországon az írástudatlanok arányát a KSH adatai szerint 2011-ben 0,5 \%-ra becsülik. ${ }^{20}$ ) A beiskolázási arány azt mutatja meg, hogy a lakosság hány százaléka tanul tovább a kötelezően elvégzett évek után. Kiszámításának módja a fentiek alapján egy százalékos értéked ad, amelynek képlete:

$$
\frac{2}{3} \mathrm{I} F+\frac{1}{3} \mathrm{KBI}
$$

Harmadik és egyben utolsó mutató az anyagi életszínvonalat bemutató egy före eső GDP-t veszi figyelembe. Ebben az esetben is van két sarokérték megadva, amelynek minimum értéke a 100 USD, felső értéke pedig 40.000 USD összegben van meghatározva. Ennek az értéknek a kiszámításár a logaritmikus számítás szükséges. A képlet a következö:

$$
\frac{\log \left(G D P_{1 f \text { öre }}\right)-\log (100)}{\log (40.000)-\log (100)}
$$

A kapott indexek önmagukban is jelentéssel bírnak, de amennyiben az összegüket átlagoljuk, megkapjuk a humán fejlettség indexét (HDI).

Bár a GDP és a HDI összehasonlítása nem túl gyakori, mivel a HDI önmagában már részeként tartalmazza a GDP értékét, Pakis ztán esetében olyan összehasonlítást találtunk, amely a GDP évenkénti változását (növekedési ütemét) és a HDI (abszolút!) értékét tárja elénk (6. ábra). Szokatlannak tünhet, hogy a meglehetősen szélsőséges értékeket produkáló GDP növekedési ütem ellenére a HDI értéke stabilan, volatilitás nélkül növekszik. Ebből is látszik az, hogy a GDP és a HDI kapcsolata gyenge. Az egyik mutató változása nem ugyanolyan mértékben és irányban okoz változást a másikban. Mahbub ul-Haq neves pakisztáni közgazdász, a HDI-t kidolgozó nemzetközi kutatócsoport vezetőjének véleménye szerint a GDP növekedés magasabb értékü lehet egy központosított katonai diktatúra égisze alatt, míg demokratikus rendszerekben a GDP esetleg lényegesen kisebb növekedést mutat, mégis a HDI magasabb értéket ér el. Így azt

${ }^{20} \mathrm{KSH}$ adatbázis, 2016. 
mondhatjuk, hogy a két mutató viszonyára, értékeire a politikai berendezkedés (is) lényeges hatással van ${ }^{21}$ - természetesen sok más puha tényezővel együtt.

\section{6. ábra. A HDI (bal tengely) és a GDP növekedési ütemének (jobb tengely) alaku- lás a Pakisztán példáján}

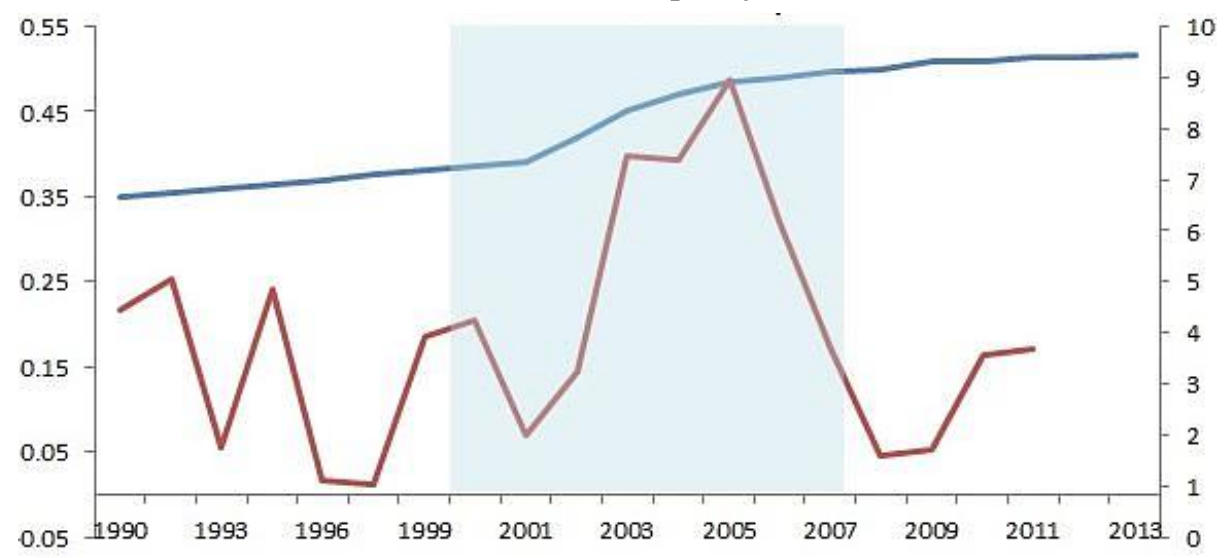

Forrás: http://www.pakalumni.com/profiles/blogs/pakistan-economic-history-1947-2010

Számos kritika fogalmazódott meg a HDI számításával kapcsolatban: többen kétségbe vonják a vizsgálatba bevont indikátorok számát, elméleti megalapozottságát, az alkalmazott súlyozást. Véleményünk szerint - amely a HDI-mutató kritikája - a hosszú és egészséges élet, az iskolázottság és a jövedelem (GDP) nem tekinthető egymástól független tényezőknek. Különösen az iskolázottság egyértelmü függvénye a jövedelem nagyságának. A kapcsolatot e területen átfogóan vizsgálja Gáspárné-Madaras-Varga (2016) tanulmánya. Hátrányai ellenére még mindig ez az egyik legsikeresebb mutató abban a tekintetben, hogy a világ 173 ors zágára már megtörtént a számítás ok elvégzése, illetve nemcsak keresztmetszeti, hanem idősoros adatok is a rendelkezésre állnak. ${ }^{22}$

\section{Összefoglalás}

Cikkünkben a GPI, az SNBI és a HDI alternatív gazdasági mutatók kialakulását, módszertanát, tulajdonságait elemeztük. Grafikonokon mutattuk a GDP-től és egymástól való eltérésüket. Az indexek GDP-hez mért különbsége elsősorban a környezeti károk figyelembe vételéből, valamint a nem piaci folyamatok elszámolásából adódik. Ezeknek az adatoknak az összegyüjtése meglehetősen nehézkes, ami nagyban hátráltatja a mutatók széleskörű és megbízható alkalmazását. Teljességre nem törekedtünk, ez nem is életszerü, mivel a mutatók nem elég elterjedtek, nem készültek még el hosszabb távú idősoros adataik. Az elemzett mutatók mindegyikének kiszámítása meghaladja a dolgozat keretét, ezzel egy későbbi tanulmányunkban szeretnénk foglalkozni. Reméljük ennyi

${ }^{21}$ Ul-Haq, 1999.

${ }^{22}$ Henderson, 1996. 
információ nemcsak segítségére lesz a KAKTUSZ-on is részt vett, vagy bármely más fiatalnak, aki ezen területtel kíván foglalkozni, de inspirálólag is hat bármely oktatóra, kutatóra, hogy e területtel foglalkozzon.

Csapatunk következő terve, - melyet továbbfejlesztési tevékenységnek is tekinthetünk - várhatóan ezen mutatók (vagy csupán közülük egy) speciális esetre (helyi, egyetemi, városi, kistérségi) történő kiszámítása lesz. Cikkünket (cikkeinket) ennek megalapozásaként is szántuk.

\section{Irodalomjegyzék}

Gáspárné, V. K., Madaras, A. és Varga, J. (2016). Regression Analysis of Influencing Factors of Public Education in Hungary. Acta Universitatis Sapientiae Economics and Business, 67-84. DOI: 10.1515/auseb-2016-0004

Görbe, A., \& Nemcsicsné, Z. Á. (1998). A jólét mérése, avagy merre halad Magyarország. Kovász, 61-75.

Henderson, H. (1996). What's next in the great debate about measuring wealth and progress? Challenge, 50-56. DOI: 10.1080/05775132.1996.11471943

KSH (2008). A humán fejlettségi mutató. 2008, június 27.

KSH adatbázis. (2016). Retrieved from www.ksh.hu

Lawn, P. A., \& Sanders, D. R. (1999). Has Australia surpassed its optimal macroeconomic scale? Finding out with the aid of 'benefit' and 'cost' accounts and a sustainable net benefit index. Ecological Economics 28, 213-229. DOI: 10.1016/S0921-8009(98)00049-4

Málovics, G. (2012). A környezeti fenntarthatóság statisztikai mérőeszközeinek fejlesztésekor jelentkező operacionalizációs választások. Regionális innovációs képesség, versenyképesség és fenntarthatóság. Szeged: JATEPress.

Neumayer, E. (2000). On the methodology of ISEW, GPI and related measures: some constructive suggestions and some doubt on the 'thres hold' hypothes is. Ecological Economics, 347-361. DOI: 10.1016/S0921-8009(00)00192-0

Szigeti, C. és Borzán, A. (2010). Ökológiai lábnyom számitása. Győr/Békéscsaba.

Talberth, J., Cobb, C., \& Slattery, N. (2007). The Genuine Progress Indicator 2006. Oakland: Redefining Progress. 2007. február. Retrieved from http://rprogress.org/ publications/2007/GPI\%202006.pdf

ul-Haq, M. (1999). Reflections on Human Development. Oxford: Oxford University Press.

UNDP (2015). Statistical annex - HUMAN DEVELOPMENT REPORT 2015. Retrieved from http://hdr.undp.org/sites/default/files/hdr_2015_statistical_annex. pdf

Unyi, I. (2007). A magyarországi folyamatok értékelése az Európai Unió indikátorai tükrében. Budapest: BGF. Retrieved from http://elib.kkf.hu/edip/D_13938.pdf

Varga, J., Bánkuti, G., Csuvár, Á., \& Sebestyénné Sz., T. (2018). A MEW és az ISEW alternatív gazdasági mutatók elméleti áttekintése. Acta Scientiarum Socialium 49: 9-16.

Varga, J., Kürthy, G., Farkas, Á. és Sipiczki, Z. (2014). A redisztribúció intézménye a piacgazdasági berendezkedés ben. E-Conom, 82-90.

DOI: $\underline{10.17836 / E C .2014 .2 .082}$

A müre a Creative Commons 4.0 standard licenc alábbi típusa vonatkozik: CC-BY-NC-ND-4.0 